\title{
SCHENGEN BORDERS CODE IN THE ASPECT OF BORDER SECURITY
}

\author{
Artūrs Gaveika \\ Rezekne Academy of Technologies, Latvia
}

\begin{abstract}
Latvia has joined the Schengen area in 2007 and has already passed three Schengen evaluations. The aim of the article is to analyse the Schengen Borders Code in the context of border security. Based on analysis of the Schengen Borders Code implementation in Latvia the author develops and puts forward suggestions on Schengen Borders Code content improvement as well as its judicial systematisation development.

The research tasks include the investigation of the current EU and national normative regulations, legal practices, the conclusions of Latvian and foreign law researchers by using analytical, historical and comparative methods.

The improvement of the national normative regulation was started long before Latvia's accession to the Schengen area. In 2006, the Schengen Borders Code entered into force, which was revised due to the migration crisis in the Mediterranean region and adopted in 2016 in an improved version. The further development of the Schengen Borders Code is important from the point of view of the right to free movement of persons and from the point of view of ensuring public security in the face of today's challenges related to terrorism, international crime, uncontrolled migration and the spread of disease.

The main achievement of the research is that the author has defined the main areas of Schengen Borders Code further development.
\end{abstract}

Keywords: Schengen Borders Code, third-country national, alien, border control, threat to public health.

JEL code: K19.

\section{Introduction}

The Schengen Borders Code was the first codified legislative act of its kind in the history of EU law to include rules on the crossing of external and internal borders, affecting not only EU citizens but also "third country" (Schengen Borders Code, 2006, Art 2) citizens and nationals, pursuing two main ideas: 1) no border checks on internal border crossing for EU citizens and third country nationals; 2) standardisation of external borders crossing. Also, in the second version, the Code was adopted by an EU Regulation and has direct effect (Schengen Borders Code, 2016) or force of law in each Schengen Member State and it does not require ratification or any transformation in the national regulatory framework. 
The topicality of the research arises from the necessity to develop the Schengen Borders Code.

The research period is mainly related to the period from 2007, when Latvia joined the Schengen area and undertook the implementation of Schengen legislation in Latvia.

The following methods were used during research:

1) The historical method - studying the development of the Schengen regulatory framework in the historical context, within the framework of the evolution of the European Union and the national regulatory framework;

2) Analytical method - analysing the international, European Union, Schengen Borders Code and national regulatory enactments, legal practices, knowledge of Latvian and foreign law scholars;

3) Comparative method - comparing different national laws, as well as relevant European Union and international regulatory framework.

The purpose and tasks of the research are to study the Schengen Borders Code current normative regulation, legal practices, the findings and conclusions of Latvian and foreign law scholars concerning Schengen Borders code implementation aspects and based on research results put forward suggestions on Schengen Acquis development.

Hypothesis - The existing content of the Schengen Borders Code and other legislative acts do not comply with modern requirements of the State Border Guard activities and do not contribute to overall efficiency of the border guards' activities. There is a need to develop further appropriate legislation which will comply with the requirements of the Schengen acquis.

The provisions of the Schengen Borders Code are without prejudice to the provisions of the Directive on the right of EU citizens and their family members to move and reside freely within the territory of Member States (Directive 2004/38/EC). However, due to the specificities of the implementation of visas related measures, the provisions of the EU (Treaty on the Functioning of the European Union, 2009, Title IV) Schengen Borders Code do not apply throughout the EU. The Schengen Borders Code defines the external borders of the EU, which are land, including river and lake borders, sea borders and airports, river ports, seaports and lake ports, provided they are not internal borders and internal borders: (a) the common land borders, including river and lake borders, of the Member States; (b) domestic airports within the Member States; (c) sea, river and lake ports of the Member States which operate a regular ferry service (Schengen Borders Code, 2016, Art 2, p 1), 2)). The definition of "river and lake borders" in the definition of the external borders of the Code is incorrect as this definition should be understood as the delimitation of the territory of rivers and lakes as separate geographical entities. 
However, in the reality, the national border line either passes through or crosses these geographical features (in the border rivers along the river axis (midline), talweg or coast). On the other hand, the definition of airports and ports as external borders is incorrect, since international law still today refers to the state border, but not to the infrastructure, and airports and ports are usually not even close to the state border but within national territory. Rather, airports and ports should be defined in the context of the regime (On the State Border of the Republic of Latvia, 2009, Art 2) of border crossing points (Schengen Borders Code, 2016, Art 2, p 8), which is not included as legal concept in the Schengen Borders Code, however, in the case of border checks, certain rules of the regime are contained in several chapters in a non-systematic way, confused with the principles of border checks. The superficiality of the definitions of external and internal borders is also evidenced by the fact that alongside the ports and airports mentioned in the definitions, it would be logical to specify road border crossing points and railway stations, but they are not specified (Regulations Regarding Border Crossing Points and Checks to be Performed Therein, Regulation No. 704, 2010).

In the Schengen Borders Code, the definition of internal borders, like the definition of external borders, incorrectly mentions river and lake borders as common borders between the Member States, but in the continuation of the definition with the phrase "National airports of the Member States, ports of sea, rivers and lakes of the Member States used for regular ferry traffic" there are several shortcomings. It is not clear from the phrase "domestic airports of the Member States" whether this refers to domestic flights within a single Member State or to flights between the Member States. Moreover, in the context of this provision, the preamble provides a different definition of 'internal flight': 'any flight exclusively to or from the territory of a Member State and not landing in the territory of a third country'. By contrast, the term "third country" is not defined in the Schengen Borders Code, but "third country national” means any person who is not a Union citizen, within the meaning of Article 20 (1) of the Treaty (Levits, 2001), (Consolidated version of the Treaty on the Functioning of the European Union, 2009, Art 20, p 1).

The sea border is an external border, because according to the Convention on the Law of the Sea, the principle of peaceful passage (United Nations Convention on the Law of the Sea (UNCLOS), 1982, Art 19) through the territorial sea, including crossing the sea border, is allowed to ships of any country, but in the context of the state border regime crossing the border is only allowed in the locations provided for this purpose (On the State Border of the Republic of Latvia, 2009, Art 11).

The Schengen Borders Code includes the term "third-country national" to be understood as any person who is not a Union citizen. Persons enjoying the right 
of free movement under Union law' means: a) Union citizens within the meaning of Article 20(1) TFEU, and third-country nationals who are members of the family of a Union citizen exercising his or her right to free movement to whom Directive 2004/38/EC of the European Parliament and of the Council (21) applies; b) thirdcountry nationals and their family members, whatever their nationality, who, under agreements between the Union and its Member States, on the one hand, and those third countries, on the other hand, enjoy rights of free movement equivalent to those of Union citizens (Directive 2004/38/EC), (Schengen Borders Code, 2016, Art 2, p 5, 6) In the Latvian Immigration Law, a person who is not a Latvian citizen or non-citizen is a foreigner. This means that it can be both a third-country national and a national of an EU Member State, the European Economic Area. However, it should be borne in mind that not all EU countries are parties to the Schengen Convention, and that there are countries which are party to the Schengen Convention but are not EU Member States. The term "third country" in the Code covers non-Schengen countries.

With the integration of the Schengen acquis into the EU legal order, the term "foreigner" was more often replaced by "third country citizen" or "third country national". There are different interpretations of the term "foreigner" in international, EU and national law. For the purposes of international law, in the Declaration on the Rights of Persons who are not Nationals of the State in which they reside (1985, Art 1), the term "alien" is used in Article 1 as a person who is not a national of the State in which he or she is. For the purposes of the Schengen Convention (1995, Art 1), "alien” shall mean any person who is not a national of a Member State of the European Community. In essence, the term "third-country national" has the same meaning as in Articles 20 to 22 of the Treaty on the Functioning of the EU, meaning that it is any person who is not an EU citizen, i.e. not a national of any EU Member State (Treaty on the Functioning of the European Union, 2009, Art 20, p 1). EU legislation and documents use both concepts. It should be noted that, in the context of expulsion, persons who enjoy the same right to free movement as EU citizens under the relevant provisions of EU law (Directive 2004/38/EC, Art 2, p 1) should be excluded from the category of third-country nationals. For the purposes of the Directive on common standards and procedures in Member States for returning illegally staying (Directive 2008/115/EC) thirdcountry nationals, "third-country national" means any person who is not an EU citizen within the meaning of Article 20 (1) of the EC Treaty. has the right to free movement within the EU as defined in Article 2 (5) of the Schengen Borders Code.

Most of the international law uses the term "alien" in a broader sense, while EU law uses the term "third-country citizen" or "third-country national" in a narrower sense. The term "alien" is also used in the Convention determining the State responsible for examining a request for asylum lodged in one of the Member States of the European Communities is incorrect translation of the word "alien" 
from English (Council Regulation (EC) No 343/2003) version to Latvia, which should rather be understood as "third-country national" meaning any person who is not a national of a Member State of the European Union, the Republic of Iceland or the Kingdom of Norway as defined in Directive 2003/110 / ECon assistance in cases of transit for the purposes of removal by air (Council Directive 2003/110/EC, Art 2, p a)) the way it used in Directive 2001/51/EC supplementing Article 26 of the Convention implementing the Schengen Agreement of 14 June 1985 (Council Directive 2001/51/EC, Art 2,3) There is also this overlap in the case law, where the term "alien is used in the context of the Schengen Convention and Law on Citizenship of Latvia and the term "foreigner" as used in the Immigration Law of Latvia.

Harmonisation of the concepts of nationality of the persons analysed within the Schengen acquis is essential for determining the status of the person required to fulfil the conditions for crossing the border and applying the relevant legal framework, where the definition and framework of legal status of persons should be correct to eliminate any diversity and subjectivity of interpretation.

Schengen Borders code includes the term 'border control' meaning the activity carried out at a border, in accordance with and for the purposes of this Regulation, in response exclusively to an intention to cross or the act of crossing that border, regardless of any other consideration, consisting of border checks and border surveillance” (Schengen Borders Code, 2016, Art 2 p 10) which was identically included in the Schengen Conventionmeaning a check carried out at a border in response exclusively to an intention to cross that border, regardless of any other consideration which from Latvian translation should be understood as border checks - checks on persons and vehicles at border crossing points in accordance with the Schengen Borders Code.

The term "border surveillance" of the Schengen Borders Code defines border surveillance between border crossing points and border crossing points at fixed hours, in order to prevent persons from circumventing border checks with the main objective of preventing unauthorised border crossings, combating crossborder crime and taking measures against persons who crossed borders illegally (Art 2, p 12, Art 13). It is clear from the Code that border surveillance applies not only to external borders but also to internal borders, although this is not explicitly stated.

In the report on the application of the Schengen Borders Code in relation to internal borders in 2010, the EC identified three issues of concern:

(1) obstacles related to possible regular and systematic checks being carried out at internal borders;

(2) obstacles to traffic flows at road crossing-points at internal borders;

(3) delayed notification of a planned reintroduction of border control at internal borders, with the tendency for the Member States to remove all obstacles 
to facilitate the flow of traffic (EK: Par Šengenas Robežu kodeksa piemērošanu. LV, 2010. 15.okt., nr.164) under Article 22 of the 2006 Schengen Borders Code, but without taking into account the obligations and powers of inland checks, in accordance with Article 21 of the Schengen Borders Code. Such EC statements were rather populist and unobtrusive as no clear and unambiguous criteria for border checks near internal borders were set. Moreover, the Schengen Borders Code at that time provided that the abolition of border control at internal borders does not affect the police powers exercised by the competent authorities of the Member States under national law, unless they are equivalent in effect to border controls (extending to border areas): does not impose border controls; is based on general police information and experience with regard to possible threats to public security and is specifically designed to combat cross-border crime; are designed and executed in such a way that they are distinct from the systematic checks on persons at the external borders; are made on a random basis (Art 21). Subsequently, in 2013/2014, the subsequent migration crisis in the Mediterranean showed the inability of the EC and other EU institutions to anticipate and prevent negative consequences in a timely manner, largely due to a lack of regulatory framework in the Schengen Borders Code and other legislation.

The EC's rather vague statement and case law confirm that the Schengen Borders Code and its subordinated regulatory framework contain an unacceptably high number of regulatory "loopholes" (Kūtris, 2008). In the present case, the operative part contains inaccuracies both in the wording 'permits and documents', without explaining what is meant by them, nor in the legal basis of the $20 \mathrm{~km}$ area, since neither the Schengen Convention nor the Code specifically provides for such. However, international law (including bilateral treaties) allows such border areas to be defined by their respective regimes.

In the context of the reintroduction of border control, the term "threat to public health" in the Schengen Borders Code, - disease which may potentially develop into an epidemic as defined by the International Health Regulations of the World Health Organization (Schengen Borders Code, 2016, Art 2 p 21) and referred security measures regarding to border checks (Schengen Borders Code, 2016, Art 7, p 2) performed on external borders just like "a serious threat to national security" is not mentioned among the reasons for reintroducing border control. Moreover, the content and meaning of the threats to "public policy" have not been revealed within the Schengen acquis. In contrast, the regulatory framework of third countries, such as Russia, for reasons of national security (also at the request of neighbouring countries) provides for the possibility of closing the state border altogether and temporarily suspending the movement of persons across the border (О Государственной границе Российской Федерации: Закон РФот 1 апреля 1993 г. N 4730-I.). A similar norm is included in the Belarusian regulatory framework (O Государственной границе Республики Беларусь: 
Закон Республики Беларусь от 21 июля 2008 г. № 419-3). Furthermore, the term "public health risk" in the Schengen Borders Code is too narrow in its scope as it only covers public health threats from disease but may also result from various emergencies, such as natural and technological disasters (accidents).

\section{Conclusions}

1. The Schengen Borders Code (2006 and 2016) and the Visa Code (2009) are the first codified legislative acts in the history of EU law to consolidate the rules on persons' border crossing of covering a substantial part of the Schengen acquis.

2. The definition of airports and ports as external borders in the Schengen Borders Code is incorrect because in international law national borders are understood to be a continuous, closed line and its coinciding plane, but not an infrastructure object. Moreover, neither airports nor ports are usually located directly on the national frontier, but on the national territory. Airports and ports are to be seen in the context of the border crossing point regime, which is not included as legal concept in the Schengen Borders Code, but with regard to border checks, certain rules of the regime are grouped in a non-systematic way mixed with border control principles.

3. For the purposes of the Schengen Convention, 'alien' means any person who is not a national of a Member State of the European Community. However, not all EU countries are members of the Schengen Convention and there are non-EU members of Schengen Convention.

4. For the purposes of the Directive on common standards and procedures in Member States for returning illegally staying third-country nationals, the term "third-country national" shall mean any person who is not an EU citizen within the meaning of Article 17 (1) who have the right to free movement within the EU, as defined in Article 2 (5) of the Code.

5. The Immigration Law of Latvia, which is particularly important for the implementation of the Schengen Convention, does not include the term 'alien' but the terms 'Union citizen' and 'foreigner' (a person who is not a Latvian citizen or a non-citizen of Latvia). Citizens of the Union who are nationals of a Member State of the European Union, of a country in the European Economic Area or of the Swiss Confederation are also to be considered as aliens by definition. In its turn, in May 2013, the Latvian Citizenship Law replaced the word 'alien' with 'citizen of another country', which is still considered a foreign national (a citizen), which is essentially identical to the term 'foreigner' in the Immigration Law. Harmonisation of the concepts of 'alien', 'third-country national' and 'foreigner' in the Schengen acquis within the framework of the Schengen acquis is crucial for 
determining the status of a person required to fulfil border crossing conditions and to apply the relevant legal framework.

\section{References}

European Commission (EC). (1995). Schengen Convention. Retrieved from https://www.refworld.org/docid/3ae6b38a20.html

European Commission (EC). (2001). Council Directive 2001/51/EC of 28 June 2001 supplementing the provisions of Article 26 of the Convention implementing the Schengen Agreement of 14 June 1985. Retrieved from https://eur-lex.europa.eu/legalcontent/EN/ALL/?uri=CELEX\%3A32001L0051

European Commission (EC). (2003). Council Directive 2003/110/EC of 25 November 2003 on assistance in cases of transit for the purposes of removal by air. Retrieved from https://eur-lex.europa.eu/legal-content/EN/TXT/?uri=CELEX:32003L0110

European Commission (EC). (2004). Directive 2004/38/EC of the European Parliament and of the Council of 29 April 2004 on the right of citizens of the Union and their family members to move and reside freely within the territory of the Member States amending Regulation (EEC) No 1612/68 and repealing Directives 64/221/EEC, 68/360/EEC, 72/194/EEC, 73/148/EEC, 75/34/EEC, 75/35/EEC, 90/364/EEC, 90/365/EEC and 93/96/EEC (Text with EEA relevance).

European Commission (EC). (2008). Directive 2008/115/EC of the European Parliament and of the Council of 16 December 2008 on common standards and procedures in Member States for returning illegally staying third-country nationals. Retrieved from https://eurlex.europa.eu/legal-content/EN/TXT/?uri=celex\%3A32008L0115

European Commission (EC). (2016). Regulation (EU) 2016/399 of the European Parliament and of the Council of 9 March 2016 on a Union Code on the rules governing the movement of persons across borders (Schengen Borders Code). Retrieved fromhttps://eur-lex.europa.eu/legal-content/EN/TXT/?uri=CELEX:32016R0399

Eiropas Komisija (EK). (2010). EK pārstāvniecības Latvijā Preses un informācijas nodaḷa. EK: Par Šengenas Robežu kodeksa piemērošanu. LV, 2010. 15.okt., nr.164.

EURLex. (2003). Convention determining the State responsible for examining applications for asylum lodged in one of the Member States of the European Communities - Dublin Convention Council Regulation (EC) No 343/2003 of 18 February 2003 establishing the criteria and mechanisms for determining the Member State responsible for examining an asylum application lodged in one of the Member States by a third-country national. Retrieved from https://eur-lex.europa.eu/legal-content/EN/TXT/?uri=CELEX: 32003R0343

EURLex. (2009). Consolidated version of the Treaty on the Functioning of the European Union. Retrieved from https://eur-lex.europa.eu/legal-content/EN/TXT/?uri=celex\% 3A12012E\%2FTXT

Kūtris, G. (2008). Likumu robi un Eiropas konstitucionālās tiesas. Eiropas konstitucionālo tiesu konferences XIV kongress. Jurista Vārds, $n r .24$. Retrieved from http://www.juristavards. lv/index.php?menu=DOC\&id=177319 
Proceedings of the International Scientific Conference. Volume VI, May $28^{\text {th }}-29^{\text {th }}$, 2021. 56-64

LR Saeima. (2009). On the State Border of the Republic of Latvia, 2009. Retrieved from https://likumi.lv/ta/en/en/id/201364

LR Saeima. (2003). Latvian Immigration Law. Retrieved from https://likumi.lv/ta/en/en /id/68522-immigration-law

LR Ministru Kabinets. (2010). Regulations Regarding Border Crossing Points and Checks to be Performed Therein. No. 704, 2010. Retrieved from https://likumi.lv/ta/en/ en/id/214844

O gosudarstvennoj granice Rossijskoi Federacii. (1993). О Государственной границе Российской Федерации: Закон РФ от 1 апреля 1993 г. N 4730-I. Retrieved from http://femida.info/11/fzoggrrf003.htmct.9.

O gosudarstvennoj granice Respubliki Belorus. (2008). О Государственной границе Республики Беларусь: Закон Республики Беларусь от 21 июля 2008 г. № 419-3. Retrieved from http://newsby.org/news/2008/07/21/text11760.htmct.5.

United Nations (UN). (1982). United Nations Convention on the Law of the Sea (UNCLOS). Retrieved from https://www.un.org/depts/los/convention_agreements/texts/unclos/ unclos_e.pdf

United Nations (UN). (1985). Declaration on the human rights of individuals who are not nationals of the country in which they live UN. Retrieved from http://www.un.org/ documents/ga/res/40/a40r144.htm

VVC. (2001). Levita E. Priekšvārds, Konsolidēts Eiropas Kopienas dibināšanas līgums un Nicas līgums. Mācību līdzeklis sabiedrisko zinātṇu studentiem. Rīga: Preses nams poligrāfijas grupā Jāņa Sēta, Retrieved from: http://www.vvc.gov.lv/export/sites/ default/LV/publikacijas/konsolidetsekligums-17.pdf 